\title{
Evaluation of Bedside Ultrasonography Use of Emergency Physicians
}

\author{
Acil Hekimlerinin Yatakbașı Ultrasonografi Kullanımlarının \\ Değerlendirilmesi
}

\author{
Kamil KOKULU D, Ekrem Taha SERT D, Hüseyin MUTLU \\ Aksaray University, Faculty of Medicine, Department of Emergency Medicine, Aksaray, Turkey \\ ORCID ID: Kamil Kokulu 0000-0002-6132-0898, Ekrem Taha Sert 0000-0002-7208-2186, Hüseyin Mutlu 0000-0002-1930-3293
}

Cite this article as: Kokulu K, Sert ET, Mutlu H. Evaluation of Bedside Ultrasonography Use of Emergency Physicians. Med J West Black Sea. 2021;5(2):182-187.

\author{
Corresponding Author \\ Kamil Kokulu \\ E-mail \\ drkokulu@gmail.com
}

Received

05.01.2021

Revision

16.01.2021

Accepted

19.01.2021

\begin{abstract}
Aim: Bedside ultrasonography (US) is a frequently used tool to facilitate diagnosis and treatment in emergency departments (EDs). The primary aim of our study was to evaluate the characteristics of emergency physicians' use of bedside US. Our secondary aim was to analyze factors affecting the regular use of bedside US.
\end{abstract}

Material and Methods: This was a descriptive cross-sectional survey study conducted with physicians working in EDs. The study was carried out using a 15 -item questionnaire in 2020 , and the results were analyzed with the Statistical Package for the Social Sciences software.

Results: The questionnaire was sent to 965 physicians working in the EDs of 48 different hospitals, and the data of $684(71.5 \%)$ that responded to all items in the questionnaire were included in the study. The EDs of the hospitals included in the study had at least one US device, and $82 \%$ of them were equipped with three probes. It was observed that $152(22.2 \%)$ of the emergency physicians did not use US at all, and $532(77.8 \%)$ used US regularly, albeit rarely. The most common area of use for US in the ED was focused assessment with sonography in trauma, followed by procedural guidance [432 (63.2\%) and 308 $(45 \%)$, respectively]. Of the physicians who did not use bedside US regularly, 33.3\% ( $n=96)$ stated that they did not use it due to their lack of training. In addition, the interest of emergency physicians in US education was measured as $7 \pm 3$ points. It was observed that the conditions associated with frequent use of bedside US were gender, inclusion of US training during residency, and duration of the availability of an US machine in the emergency clinic.

Conclusion: This study showed that emergency physicians had a high interest in using bedside US. The greatest obstacle to the use of US was insufficient training. Therefore, emergency physicians should be offered regular US training programs sand those that have not received US training should be encouraged to participate in such programs.

Keywords: Emergency department, Point-of-care ultrasound, Training

\section{ÖZ}

Amaç: Acil servislerde yatakbaşı ultrasonografi (US) teşhis ve tedavinin kolaylaştırılması için sık kullanılan bir araçtır. Çalışmamızın birincil amacı, acil hekimlerinin yatak başı US kullanım özelliklerini değerlendirmektir. İkincil amacımız ise, yatak başı US'nin düzenli uygulanmasını etkileyen faktörleri analiz etmektir.

Gereç ve Yöntemler: Çalışmamız, acil servislerde çalışan hekimler ile gerçekleştirilen tanımlayıcı kesitsel bir anket çalışmasıdır. Çalışma, 15 maddelik bir anket ile 2020 yılında gerçekleştirildi ve sonuçlar Statistical Package for Social Sciences programı ile analiz edildi. 
Bulgular: 48 farklı hastanenin acil servislerinde görev yapan 965 doktora gönderilen anketten tam doldurulan 684 (\%71.5)'ü çalışmaya alındı. Çalışmaya dahil edilen hastanelerin acil servislerinde en az bir adet US cihazı vardı ve bunların \% 82'si üç propluydu. Acil hekimlerinden 152 (\%22.2)'sinin hiç US kullanmadığı, 532 (\% 77.8)'sinin ise nadiren de olsa düzenli US kullandığı görüldü. Acil serviste US'nin en sık kullanım yeri FAST (Focused assessment with sonography in trauma), ardından ise prosedürel işlemlerdi (sırasıyla 432 [\%63.2] ve 308 [\%45]). Düzenli yatakbaşı US kullanmayan doktorların \%33.3'ünün ( $n=96)$ eğitim eksikliği nedeniyle US kullanmadığı görüldü. Ayrıca acil servis hekimlerinin US eğitimine olan ilgisi $7 \pm 3$ puan olarak ölçüldü. Yatakbaşı US'nin sık kullanımı ile ilişkili durumların: cinsiyet, US eğitiminin asistanlık eğitimi sürecinde alınmış olması ve acil kliniğinde US makinesinin mevcut olma süresi olduğu görüldü.

Sonuç: Bu çalışma, acil hekimlerinin yatakbaşı US kullanımına ilgilerinin yüksek olduğunu gösterdi. US kullanımının önündeki en büyük engel, yetersiz görülen eğitimdi. Bu sebeple acil servis hekimlerine düzenli olarak US eğitimi verilmeli ve eğitim almayanlar eğitime teşvik edilmelidir.

Anahtar Sözcükler: Acil servis, Yatakbaşı ultrasonografi, Eğitim

\section{INTRODUCTION}

In recent years, bedside ultrasonography (US) has become an increasingly used tool in many specialties, especially in emergency medicine (EM) (1). The American College of Emergency Physicians (ACEP) US manual emphasizes that emergency bedside US performed by emergency physicians constitutes a basic skill in EM applications (2). The application areas of US in the emergency department (ED) are increasing day by day, and they increase the efficacy of treatments undertaken in emergency situations (3-5). While the use of US in EDs was initially limited to focused assessment with sonography in trauma (FAST), today it has a wider range of use. In recent years, bedside emergency US has taken its place as an indispensable tool similar to a stethoscope for emergency physicians.

In order to use US in EDs, emergency physicians should be adequately trained and apply this training to clinical practice. For an effective use of US, sufficient and practical materials should be available. EM specialists working in the ED usually receive training on the use of US during their residency $(6,7)$. However, the frequency and characteristics of US use by emergency physicians in Turkey remain unknown. Therefore, the main aim of our study was to examine the US use characteristics of physicians working in EDs, and the secondary aim was to analyze factors affecting regular US use.

\section{MATERIALS and METHODS}

This prospective, cross-sectional survey study was conducted during the first 20 days of December 2020 after receiving approval from the local ethics committee (approval number: 2020/09-26). The participants were EM specialists and residents working in EDs in Turkey. Emergency physicians working in different hospitals in Turkey were invited to participate in an online survey prepared using Google Forms ${ }^{\circledR}$ software (Google, California, United States of America). The survey invitation was delivered to the participants via e-mail, SMS message, and social media groups. Individual consent was required on the first page of the questionnaire, and only those that provided consent were included in the study. The survey used in the study consisted of a total of 15 questions. Demographic information was collected, including age, gender, length of service in the ED, and professional status (EM specialist or EM resident). The following four questions inquired about explanatory factors related to whether emergency physicians received US training during residency, whether they had received US training more than once, frequency of US use, and reasons for not using US (for physicians that reported to rarely or never use US). In addition, the emergency physicians were asked about the average number of cases in which they used bedside US per month, types of bedside US they most frequently used, features of the US device in their departments, how many years the US device had been available in their departments, and whether they thought US training should be included in routine medical school curriculum. The last question measured the interest of the emergency physicians in US training based on a visual analog scale of 0 to 10 (0: not interested, 10: very interested).

In order to evaluate the frequency of US use by emergency physicians, the question, "How often do you use US in the ED?" was posed, and the responses were divided into four categories: 1- every day (in every patient with an indication for emergency US imaging in every shift), 2- regularly (at least one patient in every shift or at least once a week), 3occasionally/rarely (at least once a month), 4- never. Bedside US types performed by emergency physicians were divided into six categories: 1- FAST, 2- procedural guidance, 3- cardiac/hemodynamic assessment (evaluation of pericardial tamponade or effusion, cardiac activity/contractility in patients with cardiac arrest, hypotensive patients, and inferior vena cava), 4- abdominal assessment (e.g., abdominal aortic aneurysm, acute cholecystitis, pericholecystic fluid, and gallstones), 5- genitourinary assessment (e.g., ectopic pregnancy, hydronephrosis, pyelonephritis, globe vesicle, and urinary stones), and 6- thoracic-airway assessment (e.g., pneumothorax, pleural effusion or pneumonia, and airway and tracheal assessment) (2). 


\section{Statistical Analysis}

The responses to the Google Forms ${ }^{\circledR}$ survey were collated in a Microsoft Excel ${ }^{\circledR}$ worksheet (Microsoft, Albuquerque, United States). The statistical analysis of the data was performed using the Statistical Package for the Social Sciences version 15.0 (SPSS Inc .; Chicago, IL, USA). Qualitative data were presented as frequency and percentages. Quantitative data were expressed as mean \pm standard deviation (SD) in the case of normal distribution and as median (interquartile range [IQR]) in the case of non-Gaussian distribution. The number of EM specialists and residents in our country is approximately 4500 . The sample size was obtained through a web calculator (https://www.surveymonkey.com/mp/sample-sizecalculator/), and it was found that 580 participants with a $99 \%$ confidence interval and a $5 \%$ margin of error would be ideal.

The secondary aim of the study was to analyze factors affecting routine US use. To achieve this, two groups were compared: Group 1 consisted of physicians that stated that they used US frequently (every day or regularly) and Group 2 comprised those that reported to use US rarely or never.

Factors associated with the frequency of US use were first evaluated with a univariate logistic regression analysis. Statistically significant variables $(p<0.05)$ in the univariate analysis were further analyzed with multivariate logistic regression using the forward stepwise method. Odds ratios (ORs) and 95\% confidence intervals (Cls) were calculated for the variables included in the regression model. The fit of the multivariate logistic regression model was evaluated using the Hosmer-Lemeshow goodness-of-fit test. A p value of less than 0.05 was considered statistically significant.

\section{RESULTS}

This survey was conducted with the participation of 956 emergency physicians from 48 hospitals (10 state hospitals, 22 training and research hospitals, and 16 university hospitals). The data of 272 individuals that did not complete the survey were excluded from the study, and the study was completed with $684(71.5 \%)$ respondents. The mean age of the participants was $33.6 \pm 10.4$ years, and $60.5 \%(n=414)$ were male. The characteristics of emergency physicians are given in Table 1.

According to the results of the survey, there was at least one US device in the ED of each hospital (two in nine hospitals and more than two in six hospitals). The majority of US devices $(82 \%)$ had three probes (linear array, curvilinear array, and phased-array/cardiac), while the remainder (18\%) had only two probes (linear array and curvilinear array). Where a US device existed, there was at least one physician who used the device regularly. Of the EDs included in the study, $18.8 \%$ had been using US devices for less than five years, and $58.3 \%$ for less than 10 years.
The interest of the emergency physicians in US training was measured as $7 \pm 3$ points. Of all the participants, $84.5 \%$ (578) considered that bedside US training should be included in the routine medical school curriculum while 106 $(15.5 \%)$ participants did not agree with this idea.

Of the emergency physicians, $396(57.9 \%)$ stated that they used US every day or regularly (Group 1). There were 288 physicians who occasionally/rarely used US or never used US (Group 2). The univariate and multivariate logistic regression analysis between the two groups is presented in Table 2. We found that the physicians that received bedside US training during residency tended to perform US more frequently $(p<0.001)$. We also determined that the physicians working in clinics using US for less than 10 years used US less frequently than those working in clinics with US availability for more than 10 years $(p<0.001)$.

Table 1: Characteristics of the emergency physicians included in the study

\begin{tabular}{|c|c|}
\hline Variables & Number (\%) \\
\hline \multicolumn{2}{|l|}{ Age (years) } \\
\hline$<30$ & $304(44.4)$ \\
\hline $30-39$ & $292(42.7)$ \\
\hline $40-49$ & $64(9.4)$ \\
\hline$>50$ & $24(3.5)$ \\
\hline \multicolumn{2}{|l|}{ Gender } \\
\hline Male & $414(60.5)$ \\
\hline Female & $270(39.5)$ \\
\hline \multicolumn{2}{|l|}{ Professional status } \\
\hline Emergency medicine resident & $302(44.2)$ \\
\hline Emergency medicine specialist & $382(55.8)$ \\
\hline \multicolumn{2}{|c|}{ Duration of working in the emergency department (years) } \\
\hline$<2$ & $124(14.9)$ \\
\hline $3-5$ & $234(34.2)$ \\
\hline $6-10$ & $168(24.6)$ \\
\hline $11-20$ & $124(18.1)$ \\
\hline$>20$ & $34(5)$ \\
\hline \multicolumn{2}{|l|}{ US training status } \\
\hline $\begin{array}{l}\text { Received US training during } \\
\text { residency }\end{array}$ & $334(48.8)$ \\
\hline Received other US training & $350(51.2)$ \\
\hline \multicolumn{2}{|l|}{ Repeated US training } \\
\hline Present & $96(14)$ \\
\hline Absent & $588(86)$ \\
\hline
\end{tabular}

US: Ultrasonography 
Table 2: Comparison of emergency physicians that frequently (Group 1) and rarely (Group 2) used bedside US in the emergency department

\begin{tabular}{|c|c|c|c|c|c|c|c|}
\hline \multirow{2}{*}{ Factors affecting US use } & \multirow{2}{*}{$\begin{array}{c}\text { Group } 1 \\
\mathrm{n}=396\end{array}$} & \multirow{2}{*}{$\begin{array}{c}\text { Group } 2 \\
\mathrm{n}=\mathbf{2 8 8}\end{array}$} & \multirow[t]{2}{*}{$\mathbf{p}$} & \multicolumn{2}{|c|}{ Univariate Analysis } & \multicolumn{2}{|c|}{ Multivariate Analysis } \\
\hline & & & & OR $(95 \% \mathrm{Cl})$ & $\mathbf{p}$ & Adjusted OR (95\% Cl) & $\mathbf{p}$ \\
\hline Age (years) & $30.5 \pm 6.2$ & $35.2 \pm 4.7$ & 0.32 & $1.13(0.92-1.08)$ & 0.21 & $1.21(0.84-1.88)$ & 0.39 \\
\hline Gender & & & 0.01 & & & & \\
\hline Male & $284(71.7 \%)$ & $130(45.1 \%)$ & & 1 (Reference) & - & 1 & - \\
\hline Female & $112(28.3 \%)$ & $158(54.9 \%)$ & & $0.38(0.17-0.71)$ & 0.01 & $0.22(0.09-0.642)$ & 0.001 \\
\hline $\begin{array}{l}\text { Duration of working in the } \\
\text { emergency department (years) }\end{array}$ & & & 0.67 & & & & \\
\hline$<2$ & $81(20.5 \%)$ & $43(14.9 \%)$ & & 1 (Reference) & - & & \\
\hline $2-10$ & $231(58.3 \%)$ & $171(59.4 \%)$ & & $1.35(0.34-4.95)$ & 0.53 & $1.79(0.96-6.61)$ & 0.72 \\
\hline$>10$ & $84(21.2 \%)$ & $74(25.7 \%)$ & & $0.58(0.11-2.15)$ & 0.32 & $0.84(0.46-7.12)$ & 0.52 \\
\hline Professional status & & & 0.51 & & & & \\
\hline Emergency medicine resident & $187(47.2 \%)$ & $115(39.9 \%)$ & & 1 (Reference) & - & & \\
\hline Emergency medicine specialist & $209(52.8 \%)$ & $173(60.1 \%)$ & & $0.88(0.24-6.56)$ & 0.45 & $0.98(0.10-11.27)$ & 0.85 \\
\hline US training status & & & $<0.01$ & & & & \\
\hline $\begin{array}{l}\text { Received US training during } \\
\text { residency }\end{array}$ & $241(60.9 \%)$ & $93(32.3 \%)$ & & 1 (Reference) & - & 1 & - \\
\hline Received other US training & $155(39.1 \%)$ & $195(67.7 \%)$ & & $0.24(0.10-0.61)$ & 0.001 & $0.11(0.03-0.39)$ & $<0.001$ \\
\hline $\begin{array}{l}\text { Duration of US availability in the } \\
\text { emergency department (years) }\end{array}$ & $y_{1}$ & & 0.02 & & $\sqrt{8}$ & & \\
\hline$<5$ & $51(12.9 \%)$ & $92(31.9 \%)$ & & 1 (Reference) & & 1 & - \\
\hline $5-10$ & $163(41.2 \%)$ & $106(36.8 \%)$ & & $2.35(1.67-7.28)$ & 0.04 & $3.1(1.92-6.52)$ & 0.02 \\
\hline$>10$ & $182(46 \%)$ & $90(31.3 \%)$ & & $3.52(2.45-9.11)$ & $<0.001$ & $5.44(3.26-12.71)$ & 0.001 \\
\hline
\end{tabular}

US: Ultrasonography, Cl: Confidence interval, OR: Odds ratio.

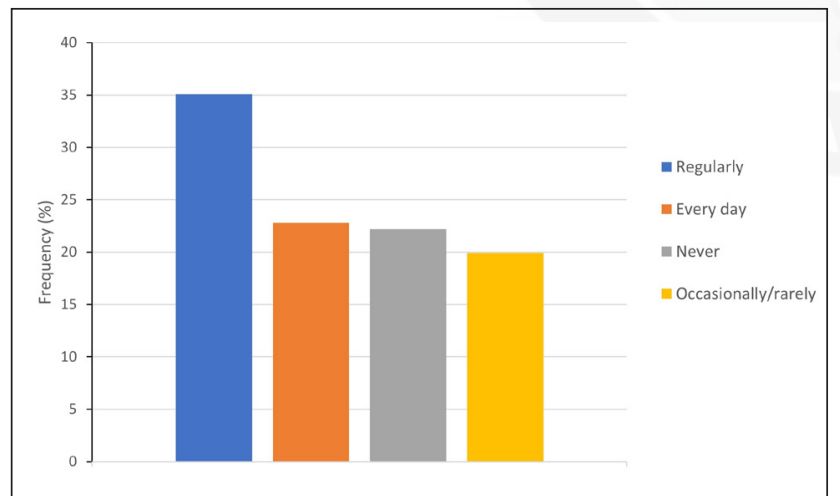

Figure 1: Frequency of the use of bedside ultrasonography by emergency physicians

The emergency physicians performed bedside US in an average of 18 (IQR 14-35) cases per month. Figure 1 shows the frequency of US use by emergency physicians. Among the different areas of US use, FAST was the most com-

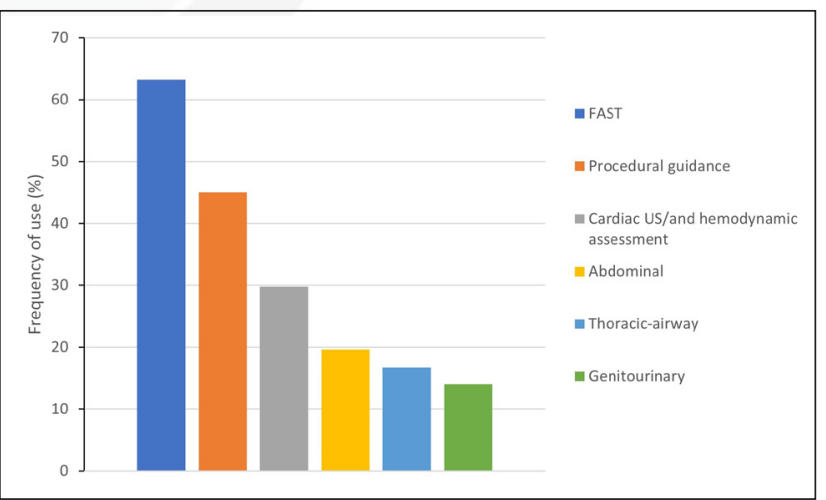

Figure 2: Types of bedside ultrasonography performed by emergency physicians. Results expressed as the percentages of 684 participants (multiple responses allowed).

mon (Figure 2). Lack of training was the main reason why the physicians in Group 2 never or only rarely performed bedside US. The reasons for not using US are presented in Figure 3. 


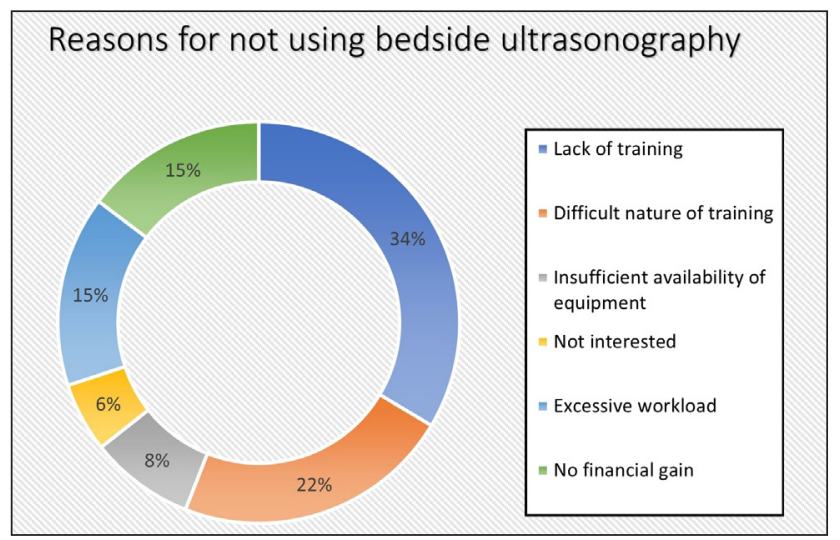

Figure 3: The reasons why emergency physicians do not use bedside ultrasonography. Results are expressed as percentages of 288 participants.

\section{DISCUSSION}

This study showed that most of the emergency physicians used bedside US ( $n=532,77.8 \%$ ). However, there were many obstacles to this application, the most important of which was insufficient US training.

Most of the hospitals where the survey was completed had at least one US device mainly used in the management of trauma patients, and FAST was the most common area of use for US. In a study published in 2018, it was reported that approximately three-quarters (71\%) of EDs in France had at least one US device, and the rate of US use was $92 \%$ (8). In other studies, the use of US was reported as $64.7 \%$ in Italy and $90 \%$ in Australia $(9,10)$. In our study, US was available in all EDs where our study was conducted, and $78 \%$ of the physicians were using bedside US. The frequency of bedside US use in the ED was similar to those reported in previous studies. However, the rate of US device availability in EDs was higher than in other countries.

In our study, it was observed that the female physicians used bedside US less frequently than men. To our knowledge, no other study has reported gender as a factor affecting bedside US use. This may probably be as a result of a bias since in our study the proportion of men that received US training during residency was higher than that of women ( $64 \%$ versus $47 \%$ ). Therefore, we consider that it is the presence or absence of US training, not gender that affects US use. We also determined that the physicians that received US training during residency used bedside US more frequently than those that received US training through other means $(p<0.001)$. The main reason for this is that US training during residency is longer in duration and involves more practice compared to other US trainings.

According to the results of our study, as the duration of US device availability in the EDs increased, the number and fre- quency of bedside US imaging applications also increased. The physicians' frequency of using US was higher in the EDs where US was used for more than 10 years compared to those in which this duration was shorter $(p<0.001)$. Previous studies have similarly shown that the frequency of US use increases in the years after physicians receive new or repeated US training $(11,12)$. It has been observed that in order to increase the use of US in EDs, bedside US training should be offered for emergency physicians and it should be repeated on a regular basis. The necessity of such training programs is supported by our finding that $34 \%$ of the physicians that did not perform bedside US attributed this to their lack of training.

Previous studies also showed that the main reason for not performing bedside US was lack of training $(13,14)$. In our study, other common reasons for not performing bedside US were the difficult nature of the training and excessive workload. Bedside US training is usually provided during residency, but apart from this, in-department trainings are also organized in hospitals for those working in EDs. In addition, US courses and symposiums are organized by physician associations. The greatest problem encountered in these programs is the lack of a consensus on the duration of practical and theoretical training. Regarding the duration of training, Bobbia et al. (15) showed that physicians that performed more than 50 echocardiographs per month had better diagnostic performance than those that performed fewer of these procedures. However, the type of training and number of US procedures to be undertaken remain controversial (16-18). Canadian guidelines recommend at least ten hours of general US training and ten hours of echocardiography training, followed by approximately 130 hours of practical US training (19).

US training objectives for emergency physicians should be clearly defined and modified if necessary by those responsible for their training. It is also necessary to encourage and standardize training programs. Establishing standards for bedside US training in Turkey as well as in Europe will increase the use of US and create a framework for US indications and application level (20). In addition, each department or hospital should schedule additional training for detailed US. Finally, in order for this training to be effective, a certain number of annual US procedures should be imposed, and proficiency exams should be planned at certain intervals.

The major limitation of our study was that the data were collected using a survey, and respondents may over report their use of US in questionnaires $(13,21)$. Therefore, an examination of the US data in the hospitals where the study was conducted can increase the accuracy of the survey. Another limitation of our study concerned the relatively small number of respondents considering the total number of physicians working in EDs in the whole country. 
In this study, we determined that there were sufficiently trained emergency physicians that used bedside US in EDs. The most common areas of use for bedside US were reported as FAST and procedural guidance. The greatest obstacle to the use of US was inadequate training, and it was found that the emergency physicians were interested in receiving such training. Regular training should be offered for emergency physicians and those that have not received such training should be encouraged to do so.

\section{Acknowledgment}

None.

\section{Author Contrubitons}

Concept, Design, Supervision: Hüseyin Mutlu, Materials, Data Collection and/or Processing: Kamil Kokulu, Analysis and/ or Interpretation, Literature Search, Writing Manuscript: Ekrem Taha Sert, Critical Review: All authors.

\section{Conflicts of Interest}

No conflict of interest was declared by the authors.

\section{Financial Support}

The authors declared that this study has received no financial support.

\section{Ethical Approval}

This study protocol was approved by the local ethics committee (Approval No: 2020/09-26) and conducted in accordance with the Declaration of Helsinki and Good Clinical Practices.

\section{Review Process}

Extremely peer-reviewed.

\section{REFERENCES}

1. Moore CL, Copel JA. Point-of-care ultrasonography. N Engl J Med 2011;364(8):749-757.

2. Ultrasound Guidelines: Emergency, Point-of-Care and Clinical Ultrasound Guidelines in Medicine. Ann Emerg Med 2017;69(5):e27-e54.

3. Bobbia X, Zieleskiewicz L, Pradeilles C, Hudson C, Muller L, Claret FG, Leone M, de La Coussaye JE, Winfocus France Group. The clinical impact and prevalence of emergency pointof-care ultrasound: A prospective multicenter study. Anaesth Crit Care Pain Med 2017;36(6):383-389.

4. Lapostolle F, Deltour S, Petrovic T. Ultrasound in emergency medicine. Ann Cardiol Angeiol (Paris) 2015;64(6):446-448.

5. Kozaci N, Avci M. Acil serviste odaklanmış kas-iskelet ultrasonografisi ile kas yaralanmalarının tanısı: Bir olgu sunumu. Anatolian J of Emerg Med 2020;3(2):58-61.

6. Değirmenci S. Role of Ultrasound Simulators in the Training for Focused Assessment with Sonography for Trauma (FAST). Ulus Travma Acil Cerrahi Derg Published online 2020. doi:10.14744/tjtes.2020.73626
7. Whitson MR, Mayo PH. Ultrasonography in the emergency department. Crit Care 2016;20(1):227.

8. Bobbia X, Abou-Badra M, Hansel N, Pes P, Petrovic T, Claret PG, Lefrant JY, La Coussaye JE, Winfocus France Group. Changes in the availability of bedside ultrasound practice in emergency rooms and prehospital settings in France. Anaesth Crit Care Pain Med 2018;37(3):201-205.

9. Sofia S, Angelini F, Cianci V, Copetti R, Farina R, Scuderi M. Diffusion and practice of ultrasound in emergency medicine departments in Italy. J Ultrasound 2009;12(3):112-117.

10. Nagaraj G, Chu M, Dinh M. Emergency clinician performed ultrasound: Availability, uses and credentialing in Australian emergency departments. Emerg Med Australas 2010;22(4):296300.

11. Henwood PC, Mackenzie DC, Rempell JS, Douglass E, Dukundane D, Liteplo AS, Leo MM, Murray AF, Vaillancourt S, Dean AJ, Lewiss RE, Rulisa S, Krebs E, Rao AKR, Rudakemwa E, Rusanganwa V, Kyanmanywa P, Noble VE. Intensive pointof-care ultrasound training with long-term follow-up in a cohort of Rwandan physicians. Trop Med Int Health 2016;21(12):15311538.

12. Bell G, Wachira B, Denning G. A pilot training program for pointof-care ultrasound in Kenya. Afr J Emerg Med 2016;6(3):132137.

13. Leschyna M, Hatam E, Britton S, Myslik F, Thompson D, Sedran R, VanAarsen K, Detombe S. Current state of point-ofcare ultrasound usage in Canadian Emergency Departments. Cureus 2019;11(3):e4246.

14. Sanders JL, Noble VE, Raja AS, Sullivan AF, Camargo CA. Access to and use of point-of-care ultrasound in the emergency department. West J Emerg Med 2015;16(5):747-752.

15. Bobbia X, Pradeilles C, Claret PG, Soullier C, Wagner P, Bodin Y, Roger C, Cayla G, Muller L, de La Coussaye JE. Does physician experience influence the interpretability of focused echocardiography images performed by a pocket device? Scand J Trauma Resusc Emerg Med 2015;23(1):52.

16. Filler L, Orosco D, Rigdon D, Mitchell C, Price J, Lotz S, Stowell JR. Evaluation of a novel curriculum on point-of-care ultrasound competency and confidence. Emerg Radiol 2020;27(1):37-40.

17. Koratala A, Segal MS, Kazory A. Integrating point-of-care ultrasonography into nephrology fellowship training: A model curriculum. Am J Kidney Dis 2019;74(1):1-5.

18. Amini R, Adhikari S, Fiorello A. Ultrasound competency assessment in emergency medicine residency programs. Acad Emerg Med 2014;21(7):799-801.

19. Arntfield RT, Millington SJ, Ainsworth CD, Arora R, Boyd J, Finlayson G, Gallagher W, Gebhardt C, Goffi A, Hockman E, Kirkpatrick A, McDermid R, Waechter J, Wong N, Zavalkoff $\mathrm{S}$, Beaulieu Y. Canadian recommendations for critical care ultrasound training and competency. Can Respir J 2014;21(6):341-345.

20. Michels G, Zinke H, Möckel M, Hempel D, Busche C, Janssens U, Kluge S, Riessen R, Buerke M, Kelm M, von Bardeleben RS, Knebel F, Busch HJ. Recommendations for education in ultrasound in medical intensive care and emergency medicine: Position paper of DGIIN, DEGUM and DGK. Med Klin Intensivmed Notfmed 2017;112(4):314-319.

21. Lesage $B$, Martinez $M$, Lefebvre $T$, Cavalli $P$, Cailasson $L$, Leger M, d'Arras AC, Boyer A, Redjaline A, Viallon A. Practice of emergency point-of-care ultrasound in a French emergency medicine network. Ann Fr Med Urgence 2019;9(1):33-40. 